DOI: $10.6060 / \mathrm{mhc} 180794 \mathrm{~b}$

\title{
Influence of Fluorosubstitution on the Structure of Zinc Phthalocyanine Thin Films
}

\author{
Darya D. Klyamer, ${ }^{\mathrm{a}, \mathrm{b}}$ Aleksandr S. Sukhikh, ${ }^{\mathrm{a}, \mathrm{b}}$ Sergey A. Gromilov, ${ }^{\mathrm{a}, \mathrm{b}}$ \\ Vladimir N. Kruchinin, ${ }^{\mathrm{c}}$ Evgeniy V. Spesivtsev, ${ }^{\mathrm{c}}$ Aseel K. Hassan, ${ }^{\mathrm{d}}$ \\ and Tamara V. Basova ${ }^{a, b} @$
}

\author{
aNikolaev Institute of Inorganic Chemistry SB RAS, 630090 Novosibirsk, Russia \\ ${ }^{\mathrm{b}}$ Novosibirsk State University, 630090 Novosibirsk, Russia \\ ${ }^{c}$ Rzhanov Institute of Semiconductor Physics SB RAS, 630090 Novosibirsk, Russia \\ ${ }^{\mathrm{d}}$ Materials and Engineering Research Institute, Sheffield Hallam University, Sheffield, UK \\ ${ }^{\circledR}$ Corresponding authorE-mail: basova@niic.nsc.ru
}

\begin{abstract}
In this work, thin films of tetrafluorosubstituted zinc phthalocyanine $\left(\mathrm{ZnPc} \mathrm{F}_{4}\right)$ were deposited by organic molecular beam deposition and studied to reveal the effects of F-substituents on the $\mathrm{ZnPcF}_{4}$ single crystals and thin films structure. A combination of spectral ellipsometry, atomic force microscopy and diffraction techniques has been used to elucidate the structural features and molecular orientation of thin films of $\mathrm{ZnPcF}_{4}$. Structural features of the films grown by coevaporation of $\mathrm{ZnPc}$ and $\mathrm{ZnPcF}_{4}(1: 1)$ were also considered. Both $\mathrm{ZnPcF}_{4}$ and $\mathrm{ZnPc} / \mathrm{ZnPcF}{ }_{4}$ films have a preferred orientation along (001) plane with inclination angle of molecules relative to the substrate surface equal to $80^{\circ}$ and the lower degree of crystallinity compared to the ZnPc film.
\end{abstract}

Keywords: Zinc phthalocyanines, thin films, orientation, crystal structure.

\section{Влияние фторзамещения на структуру тонких пленок фталоцианината цинка}

\author{
A. Клямер, ${ }^{\mathrm{a}, \mathrm{b}}$ A. Сухих, ${ }^{\mathrm{a}, \mathrm{b}}$ C. Громилов, ${ }^{\mathrm{a}, \mathrm{b}}$ B. Кручинин, ${ }^{\mathrm{c}}$ Е. Спесивцев, ${ }^{\mathrm{c}}$ А. Хассан, ${ }^{\mathrm{d}}$ \\ T. Басова ${ }^{a, b @}$
}

${ }^{\mathrm{a}}$ Институт неорганической химии им. А.В. Николаева СО РАН, 630090 Новосибирск, Россия

${ }^{\mathrm{b}}$ Новосибирский национальный исследовательский государственный университет, 630090 Новосибирск, Россия

'Институт физики полупроводников им. А.В. Ржанова СО РАН, 630090 Новосибирск, Россия

${ }^{\mathrm{d}}$ Институт материалов и машиностроения, Шеффилд Халлам Университет, Шеффилд, Великобритания

${ }^{\circledR}$ E-mail: basova@niic.nsc.ru

\begin{abstract}
В настоящей работе проводится исследование тонких пленок тетрафторзамещенного фталоцианината цинка (ZnPcF $)$, полученных методом осаждения из молекулярного пучка в вакууме. Для выявления влияния F-заместителей во фталоцианиновом кольце на структуру монокристалла и тонких пленок ZnPcF ${ }_{4}$ проведено их сравнительное исследование с незамещенным аналогом ZnPc. Для исследования структурных особенностей и ориентации пленок использовалась комбинация методов спектральной эллипсометрии, атомной силовой микроскопии и рентгеновской дифракции. Кроме того, было проведено исследование пленок,

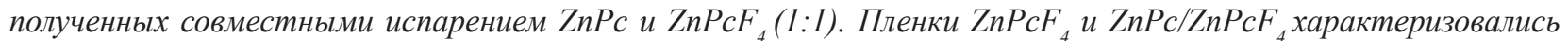
преимущественной ориентацией кристаллитов вдоль направления (001) и углом наклона молекул относительно поверхности подложки $80^{\circ}$ и имели более низкую степень кристалличности по сравнению с пленками ZnPc.
\end{abstract}

Ключевые слова: Фталоцианинаты цинка, тонкие пленки, ориентация, кристаллическая структура. 


\section{Introduction}

Thin films of both unsubstituted and substituted metal phthalocyanine (MPc) derivatives are of considerable interest as active layers of chemical sensors ${ }^{[1,2]}$ and field effect transistors. ${ }^{[3-5]}$

Introduction of various substituents into the phthalocyanine macrocycle can significantly alter thin films structure and morphology and in its turn leads to the change of their electrical and sensing properties. ${ }^{[6-11]}$ Introduction of electron withdrawing fluorine substituents has been shown to change the molecular packing both in single crystals ${ }^{[12-14]}$ and in thin films ${ }^{[15]}$ compared to unsubstituted phthalocyanines. The structure of $\mathrm{MPcF}_{16}(\mathrm{M}=\mathrm{Cu}, \mathrm{Co}, \mathrm{Zn})$ single crystals grown by vacuum evaporation was found to be triclinic, with two molecules per unit cell and herringbone stacking. ${ }^{[13-14]}$ Single crystals of unsubstituted MPcs grown at the same experimental conditions are monoclinic with herringbone arrangement of phthalocyanine macrocycles. ${ }^{[16]}$

It is well known that in the case of unsubstituted M(II) Pcs, the substrate temperature during deposition affects the morphology, phase composition and ordering of thin films. In the case of $\mathrm{MPcF}_{16}(\mathrm{M}=\mathrm{Co}, \mathrm{Cu})$ films, it was shown that the substrate temperature and post-deposition annealing also cause the change of films morphology, ${ }^{[3,17]}$ however $\mathrm{CuPcF}_{16}$ films exhibit the same phase composition independently of the deposition temperature. ${ }^{[15]}$ Morphology and structure of $\mathrm{MPcF}_{16}$ films are dependent on their thickness. ${ }^{[18]}$ Yang et al. have shown that caterpillar-like crystal structure changes to nanobelt structure when thickness of the films becomes more than $30 \mathrm{~nm}$.

F-substituents decrease the electron density of the aromatic ring and increase the oxidation potential of the MPc molecule. ${ }^{[19]}$ As a result, fluorosubstituted phthalocyanines exhibit the higher sensor response to such reducing gases as ammonia and hydrogen. ${ }^{[16]}$ The better sensor response of $\mathrm{ZnPcF}_{16}$ and $\mathrm{PdPcF}_{16}$ films towards gaseous ammonia compared to their unsubstituted analogues was shown by Schollhorn et al. ${ }^{[20-21]}$ and Klyamer et al., ${ }^{[6]}$ respectively. It is well known that optical, electrical and sensing properties the phthalocyanine films might differ significantly in dependence on their structure and ordering. ${ }^{[6,8]}$ Moreover, fluorosubstituted metal phthalocyanines are used as $n$-type semiconductors for the preparation of ambipolar devises, e.g. organic field effect transistors, in combination with unsubstituted metal phthalocyanines or other organic molecules in bilayer architectures or as blends. ${ }^{[4,9,10]}$ For this reason the detailed study of structural features of fluorinated phthalocyanine films grown under different experimental conditions is an important task of materials chemistry.

To the best of our knowledge, only sporadic data on structure and properties of tetrafluorosubstituted metal phthalocyanine $\left(\mathrm{MPcF}_{4}\right)$ films are available in the literature. ${ }^{[6-7,22]}$ Schlettwein et al. ${ }^{[22]}$ analyzed the influence of fluorination degree in $\mathrm{ZnPcF}_{\mathrm{x}}(\mathrm{x}=0,4,8,16)$ films on their optical and electrical properties. Schwarze et al. ${ }^{[23]}$ studied thin films of $\mathrm{ZnPcF}_{\mathrm{x}}(\mathrm{x}=4,8,16)$ co-evaporated with $\mathrm{ZnPc}$ onto glass substrates in various mixing ratios. Ultra thin films of $\mathrm{CuPcF}_{4}$ on gold and ITO surfaces were studied by photoemission spectroscopy. ${ }^{[24-25]}$ Structural features and sensor response of $\mathrm{CoPcF}_{4}$ films toward ammonia were studied by Klyamer et al. ${ }^{[6]}$ Structure of single crystals of $\mathrm{PdPcF}_{4}$ has been published in our recent work. ${ }^{[7]}$ The parameters of crystal cell of $\mathrm{MPcF}_{4}(\mathrm{M}=\mathrm{Cu}, \mathrm{Zn})$ were reported by Jiang et al., ${ }^{[11]}$ however the authors did not give the full data of single crystal structures and did not deposit the crystallographic data in the Cambridge Crystallographic Data Centre (CCDC). The detailed investigation of the structure and ordering of $\mathrm{MPcF}_{4}$ films has also not yet been described in the literature.

In this work, thin films of tetrafluorosubstituted zinc phthalocyanine $\left(\mathrm{ZnPcF}_{4}\right)$ were deposited by organic molecular beam deposition (OMBD) and studied to reveal the effects of F-substituents on the $\mathrm{ZnPcF}_{4}$ thin films structure. The crystalline structure of $\mathrm{ZnPcF}_{4}$ single crystals has been refined using X-ray diffraction (XRD) measurements and their crystallographic data have been deposited in the Cambridge Crystallographic Data Centre with the reference number 1818040. A combination of spectral ellipsometry, atomic force microscopy (AFM) and XRD techniques have been used to elucidate the structural features and molecular orientation of thin films of $\mathrm{ZnPcF}_{4}$. Structural features of the films grown by co-evaporation of $\mathrm{ZnPc}$ and $\mathrm{ZnPcF}_{4}(1: 1)$ are also considered.

\section{Experimental}

$\mathrm{ZnPcF}_{4}$ was synthesized by heating a 4:1 mixture of 4-fluorophthalonitrile (Aldrich) and anhydrous zinc(II) chloride in a glass tube at $220{ }^{\circ} \mathrm{C}$ during 6 hours. The resulted product was purified by gradient sublimation in vacuum $\left(10^{-5}\right.$ Torr) at $450{ }^{\circ} \mathrm{C} . \mathrm{ZnPcF}_{4}$ was prepared as a statistical mixture of four regioisomers due to the various possible positions of fluorine substituents. No attempt was made to separate the $\mathrm{ZnPcF}_{4}$ isomers. $\mathrm{ZnPc}$ (Aldrich) was also purified by gradient sublimation in vacuum $\left(10^{-5}\right.$ Torr $)$ at $450{ }^{\circ} \mathrm{C}$.

The $\mathrm{ZnPc}$ and $\mathrm{ZnPcF}_{4}$ thin films were prepared by an $\mathrm{OMBD}$ technique at the substrate temperature of $60{ }^{\circ} \mathrm{C}$. The evaporation was performed at a residual pressure of $10^{-5}$ Torr. The deposition rate was $0.6 \mathrm{~nm} \cdot \mathrm{s}^{-1}$. The mixed films (further referred to as $\mathrm{ZnPc}$ / $\mathrm{ZnPcF}_{4}$ film) were obtained by co-evaporation of $\mathrm{ZnPc}$ and $\mathrm{ZnPcF}_{4}$ (1:1) at the same conditions. The chemical composition of the mixed films was determined by X-ray photoelectron spectroscopy (XPS) using a Phoibos-150 SPECS spectrometer (monochromatic AlKaradiation, beam diameter $c a .1 \mathrm{~mm}$ ).

The dispersive refractive indexes $\mathrm{N}(\lambda)=\mathrm{n}(\lambda)-\mathrm{k}(\lambda) i$ and thicknesses for $\mathrm{ZnPc}$ and $\mathrm{ZnPcF}_{4}$ films were obtained as a function of wavelength $\lambda$ by means of spectroscopic ellipsometry. The spectral dependences of ellipsometric parameters $\Psi$ and $\Delta$ were carried out using spectroscopic ellipsometer ELLIPS 1771 SA (ISP, Novosibirsk, Russia) over the range of $\lambda=250-1100 \mathrm{~nm} .^{[26]}$ The spectral resolution of the instrument was $2 \mathrm{~nm}$; the light beam angle of incidence was $70^{\circ}$. The solution of the inverse problem of ellipsometry and fitting of the spectral dependences of ellipsometric angles $\Psi(\lambda)$ and $\Delta(\lambda)$ were performed in accordance with the basic equation of ellipsometry:

$$
\operatorname{tg} \Psi \cdot e^{-i \Delta}=R_{p} / R_{s},
$$

where $R_{\mathrm{p}}$ and $R_{\mathrm{s}}$ are the $\mathrm{p}$ - and s-components of the complex Fresnel reflection coefficients, respectively. ${ }^{[27]}$ In the calculations, the model of reflecting system "substrate - uniform film - air" was employed. Thus, in the whole spectral range, the spectral dependences of polarization angles were fitted for 
each point of the spectrum independently by the error function minimization:

$$
\sigma^{2}=\left(\frac{\Delta_{\text {exp. }}-\Delta_{\text {calc. }}}{\delta \Delta_{\text {err. }}}\right)^{2}+\left(\frac{\Psi_{\text {exp. }}-\Psi_{\text {calc. }}}{\delta \Psi_{\text {err. }}}\right)^{2}
$$

where $\Psi_{\text {exp. }}, \Delta_{\text {exp. }}$ and $\Psi_{\text {calc. }}, \Delta_{\text {calc. }}$ are experimental and calculated values of the ellipsometric parameters, while $\delta \Psi_{\text {err }}, \delta \Delta_{\text {err }}$ are experimental error values. Previously the film thickness was obtained at wavelength $\lambda=500 \mathrm{~nm}(\mathrm{k} \sim 0)$. Solution of the multiangle ellipsometric (MAE) inverse problem was carried out in the framework of the model "Si substrate - uniform film - air". Then the thickness values were used in the dispersive optical parameter calculations.

AFM in tapping mode with a Nanoscope IIIa (Veeco Instruments, Plainview, U.S.A.) scanning probe microscope was used for films morphology characterization. UV-Vis spectra of $\mathrm{ZnPc}$ and $\mathrm{ZnPcF}_{4}$ solutions and films on quartz substrates were recorded using a UV-Vis-NIR scanning spectrophotometer (UV-Vis-3101PC "Shimadzu"). Raman spectra were collected using a LabRAM HR Evolution (Horiba) spectrometer with the excitation by the $488 \mathrm{~nm}$ line of the Ar laser. IR spectra were recorded using a Vertex 80 FTIR spectrometer.

X-ray structure determination of $\mathrm{ZnPcF}_{4}$ was carried out using a Bruker DUO single crystal diffractometer (4-circle kappa-goniometer, Mo-anode sealed tube, graphite monochromator, Apex II CCD area-detector, $1024 \times 1024$ pixels with $60 \mu \mathrm{m}$ pixel size) using conventional phi- and omega-scans $\left(0.5^{\circ}\right.$ wide). Sample temperature was kept at $160 \mathrm{~K}$ by Oxford Cryosystems Cobra nitrogen open-flow cooler. X-ray diffraction patterns for polycrystalline powders were obtained at room temperature using Shimadzu XRD-7000 powder diffractometer $(\mathrm{Cu}$-anode sealed tube, Ni-filter, Bragg-Brentano geometry, $\theta-\theta$ goniometer, scintillation counter). Thin films samples were studied using combination of a XRD-7000 diffractometer for standard powder patterns and Bruker DUO diffractometer (Incoatec $\mathrm{I} \mu \mathrm{Cu}$ microfocus source, $0.6 \mathrm{~mm}$ monocapillary focusing collimator) for $2 \mathrm{D}$ GIXD (2D Grazing incidence X-ray diffraction) patterns using a special sample adaptor. The primary beam angle of incidence was in the range from 0.3 to $0.5^{\circ}$. The distance from the sample to the CCD detector was $80 \mathrm{~mm}$. This method has already been described ${ }^{[28-29]}$ in more details.

\section{Results and Discussion}

\section{Structure of $\mathrm{ZnPcF}_{4}$ Single Crystals}

Single crystals of $\mathrm{ZnPcF}_{4}$ were obtained by sublimation of the respective polycrystalline powder in a gradient furnace at $450{ }^{\circ} \mathrm{C}$ for 2 hours under vacuum (residual pressure $\sim 2 \cdot 10^{-5}$ Torr). An optical image of the obtained crystals is shown in Figure 1. Crystallographic data for $\mathrm{ZnPcF}_{4}$ have been deposited in the Cambridge Crystallographic Data Centre (CCDC) with the reference number 1818040. $\mathrm{ZnPcF}_{4}$ formed dense clusters of needle-shaped crystals with dark violet color and metallic shine, which is typical for unsubstituted and fluorinated phthalocyanines. ${ }^{[14]}$

$\mathrm{X}$-ray diffraction patterns for $\mathrm{ZnPc}$ and $\mathrm{ZnPcF}_{4}$ polycrystalline powders obtained in the range from 2.5 to $40^{\circ}$ $2 \theta$ are shown in Figure 2. The $\mathrm{ZnPc}$ powder pattern fully coincides with the calculated one on the basis of the known $\beta-Z n P c$ structural data ${ }^{[30]}$ (monoclinic $P 2 / a, a=19.274(5)$, $\left.b=4.8538(15), c=14.553(4) \AA, \beta=120.48(2)^{\circ}\right)$. The $\mathrm{ZnPcF}_{4}$ powder pattern is similar to that of $\mathrm{CoPcF}_{4}$ and $\left.\mathrm{PdPcF}_{4} \mathrm{I}_{4}, 7\right]$ and has single phase composition. Crystal structure

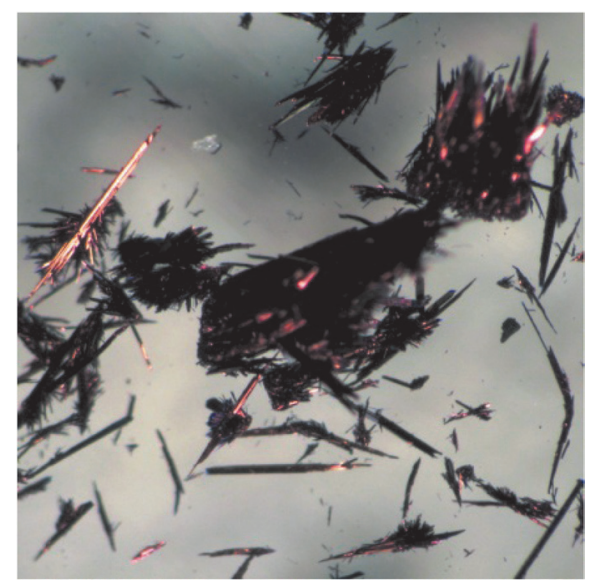

Figure 1. Microscopic image of $\mathrm{ZnPcF}_{4}$ crystals.

of $\mathrm{ZnPcF}_{4}$ was determined by the means of single crystal $\mathrm{X}$-ray diffraction. A small $(250 \times 20 \times 15 \mu \mathrm{m})$ needle-shaped crystal was mounted on a nylon loop with liquid epoxy. The Bruker APEX II software package (SAINT, SADABS) ${ }^{[3]}$ was used for indexing, collecting raw data, integration of diffraction reflections, global unit cell refinement and absorption correction. The resulting dataset was processed in Olex 2 v1.2.9, ${ }^{[32]}$ with SHELXT-2014/5 $5^{[33]}$ and SHELXL-2017/1 $1^{[34]}$ used for structure determination and subsequent refinement. All non-hydrogen atom positions were refined anisotropically, without additional restraints. Fluorine atoms occupancy was refined as a free variable, based on the assumption that the total occupancy for two neighbouring positions should be equal to 1 . The resulting occupancy values are $0.478 / 0.522$ for F1 and F2 and $0.438 / 0.562$ for F3 and F4, respectively (see Figure 3a).

The noticeable deviation from 0.5 is apparently caused by uneven proportions of $\mathrm{ZnPcF}_{4}$ isomers. Hydrogen atoms were refined using the aromatic/amide riding coordinates. Since fluorine atoms occupy 8 peripheral positions only partially, hydrogen atoms with the complementary occupancy were added to the structure, therefore the total occupancy of each peripheral position is equal to one. Unit cell parameters and details of the structure refinement are given in Table 1.

Packaging diagrams for $\mathrm{ZnPcF}_{4}$ are shown in Figure 3b. $\mathrm{ZnPcF}_{4}$ molecule retains relatively flat conformation with all carbon, nitrogen and fluorine atoms deviating out of mean squared plane no more than $0.15 \AA$. The angles between peripheral benzene rings and the central macrocycle are $1.6^{\circ}$ and $6.2^{\circ} . \mathrm{ZnPcF}_{4}$ molecules are packed similarly to low-temperature metastable $\alpha$-phases of unsubstituted $\mathrm{M}(\mathrm{II}) \mathrm{Pcs}(\mathrm{M}=\mathrm{Co}, \mathrm{Cu}){ }_{{ }^{[35]}} \mathrm{PdPcF}_{4}{ }^{[7]}$ and $\mathrm{CuPcF}_{4}{ }^{[11]}$ with $Z=1$, triclinic system and $P-1$ space group, however the space group and its unit cell parameters differ from those determined for $\mathrm{ZnPcF}_{4}$ by Jiang et al. ${ }^{[1]}$ The distance between individual $\mathrm{ZnPcF}_{4}$ molecules within a stack is $3.33 \AA$ ( $3.41 \AA$ for $\alpha$-CoPc, $3.44 \AA$ for $\alpha$-CuPc and $3.37 \AA$ for $\mathrm{PdPcF}_{4}$ ), with $3.68 \AA$ between the neighbouring $\mathrm{Zn}$ atoms and with the stacking angle (the angle between the least squares plane of the molecule and the line going through $\mathrm{Zn}$ atoms within a stack) $\theta=25.31^{\circ}\left(24.58^{\circ}\right.$ for $\alpha-\mathrm{CoPc}, 25.21^{\circ}$ for $\alpha$-CuPc and $23.44^{\circ}$ for $\mathrm{PdPcF}_{4}$ ). 


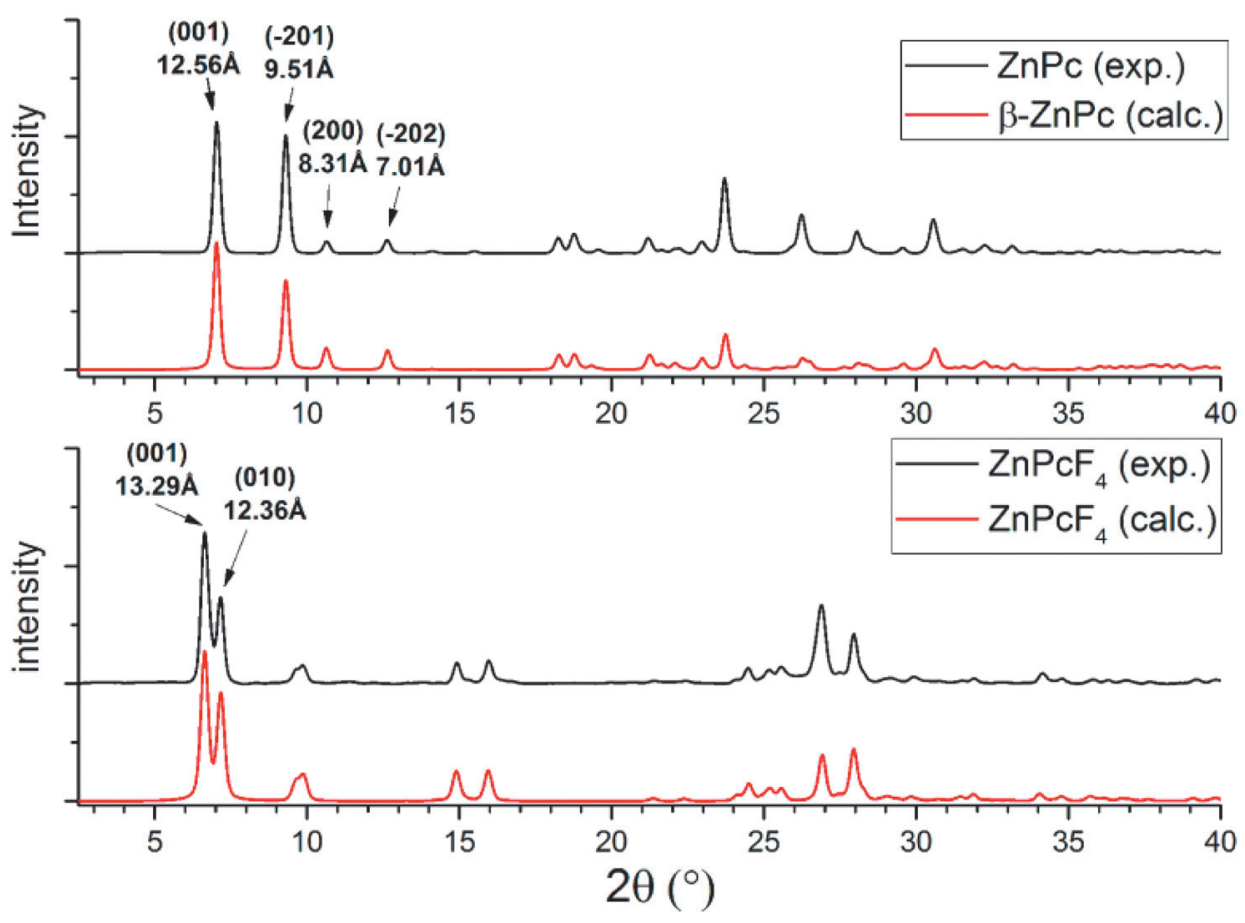

Figure 2. Diffraction patterns for $\mathrm{ZnPc}$ and $\mathrm{ZnPcF}_{4}$ polycrystalline powders (Shimadzu XRD-7000, $\mathrm{CuK}_{\alpha}$-radiation, Bragg-Brentano geometry).
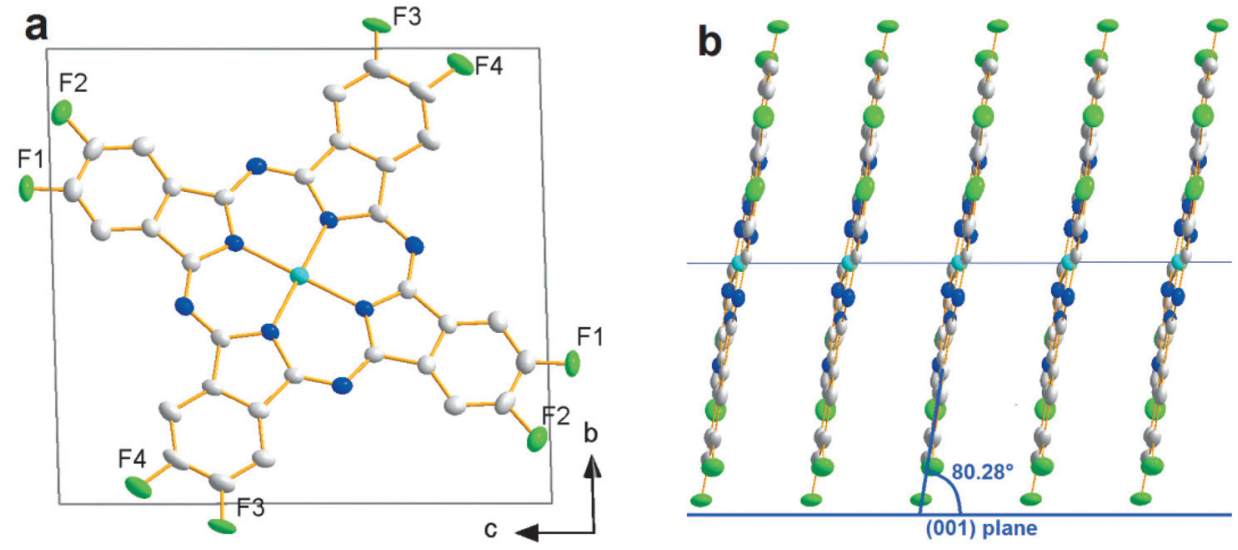

Figure 3. Packaging diagrams for $\mathrm{ZnPcF}_{4}$ : as viewed along axis (a) and along (001) lattice plane (b). Occupancy values are $0.478 / 0.522$ for $\mathrm{F} 1$ and $\mathrm{F} 2$ and $0.438 / 0.562$ for $\mathrm{F} 3$ and $\mathrm{F} 4$, respectively.

\section{Study of $\mathrm{ZnPc}$ and $\mathrm{ZnPcF}_{4}$ Thin Films}

Dispersion dependences of the refractive index $\mathrm{n}(\lambda)$ and the extinction coefficient $\mathrm{k}(\lambda)$ calculated from the $\Psi(\lambda)$, $\Delta(\lambda)$ ellipsometric angle dependences for $\mathrm{ZnPc}, \mathrm{ZnPcF}_{4}$ and mixed $\mathrm{ZnPc} / \mathrm{ZnPcF}_{4}$ films are shown in Figure 4. There are two groups of the absorbance maxima in the spectra of the films which are typical for the most metal phthalocyanines: ${ }^{[36-37]}$ the broad $B$-band at $\sim 334 \mathrm{~nm}$ and the $Q$-band consisting of two peaks at $\sim 580-630 \mathrm{~nm}$ and at $\sim 710 \mathrm{~nm}$. The shift of the $Q$-band from $\sim 580 \mathrm{~nm}$ to $\sim 630 \mathrm{~nm}$ is observed in the $\mathrm{k}(\lambda)$ spectrum of $\mathrm{ZnPcF}_{4}$ film, which appears to be due to the effect of electron withdrawing substituents. The thickness of the $\mathrm{ZnPc}, \mathrm{ZnPcF}_{4}$ and mixed $\mathrm{ZnPc} / \mathrm{ZnPcF}_{4}$ films (Figure 4) were estimated from the ellipsometry data to be $49.2,80.6$ and $75.2 \mathrm{~nm}$, respectively.

Figure 5 shows AFM images of the surface of $\mathrm{ZnPc}$ (a) and $\mathrm{ZnPcF}_{4}$ (b) films as well as a film obtained by coevaporation of $\mathrm{ZnPc}$ and $\mathrm{ZnPcF}_{4}$ (1:1) (c). As can be clearly seen both $\mathrm{ZnPc}$ and $\mathrm{ZnPcF}_{4}$ films exhibit a high density of azimuthally disordered roundish grains (Figure 5a), however the grain sizes of $\mathrm{ZnPcF}_{4}$ film are noticeably smaller than those of $\mathrm{ZnPc}$ films (Figure 5b). The rms roughness values of $\mathrm{ZnPc}$ and $\mathrm{ZnPcF}_{4}$ films were 14.2 and $6.0 \mathrm{~nm}$, respectively. The film obtained by co-evaporation of $\mathrm{ZnPc}$ and $\mathrm{ZnPcF}_{4}$ was smoother than the single-phase films and had the rms value $5.3 \mathrm{~nm}$ (Figure $5 \mathrm{c}$ ). It is worth mentioning that the actual ratio $\mathrm{ZnPc} / \mathrm{ZnPcF}_{4}$ in the films 
Table 1. Unit cell parameters and refinement statistics for $\mathrm{ZnPcF}_{4}$.

\begin{tabular}{cc}
\hline Compound & $\mathrm{ZnPcF}_{4}$ \\
\hline Formula & $\mathrm{Zn}_{1} \mathrm{C}_{32} \mathrm{~N}_{8} \mathrm{~F}_{4} \mathrm{H}_{12}$ \\
F.W. & 649.87 \\
T, K & 160 \\
System & Triclinic \\
Space group & $P-1$ \\
$Z$ & 1 \\
$a, \AA$ & $3.6843(5)$ \\
$b, \AA$ & $12.381(2)$ \\
$c, \AA$ & $13.371(2)$ \\
$\alpha,{ }^{\circ}$ & $88.368(5)$ \\
$\beta,^{\circ}$ & $88.621(4)$ \\
$\gamma,{ }^{\circ}$ & $84.956(5)$ \\
Volume, $\AA^{3}$ & $607.18(15)$ \\
Density (calc), g/sm ${ }^{3}$ & 1.777 \\
$\mathrm{R}_{1}(\mathrm{I}>2 \theta), \%$ & 5.19 \\
\hline
\end{tabular}

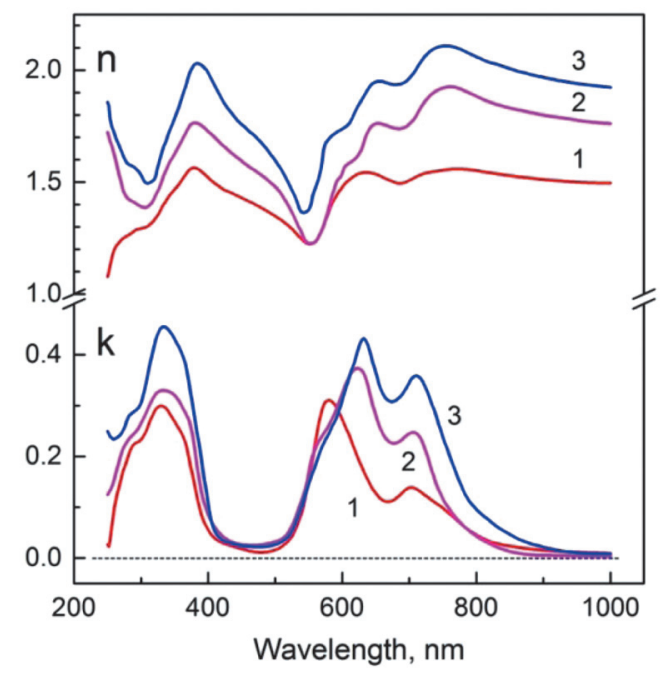

Figure 4. Dispersion dependences $n(\lambda), \mathrm{k}(\lambda)$ for $\mathrm{ZnPc}(1), \mathrm{ZnPcF}_{4}$ (3) and mixed $\mathrm{ZnPc} / \mathrm{ZnPcF}_{4}$ (2) films. Thicknesses of the films (nm): $1-49.2,2-80.6,3-75.2$. on the ITO coated glass substrate was estimated by means of XPS to be about 0.9 .

$\mathrm{X}$-ray diffraction patterns of thin films in the range from 5 to $30^{\circ} 2 \theta$ are shown in Figure 6 . All three diffraction patterns contain a single strong diffraction peak in the $2 \theta$ range of $6-7^{\circ}$, which is typical for most of M(II)Pc films ${ }^{[6-7]}$ and this usually means that the samples have a significant degree of preferred orientation relative to the substrate surface.

For $\mathrm{ZnPc}$ the measured interplanar distance (d) of this peak $12.69 \AA$ noticeably differs from the position of (001) peak of $\beta$-ZnPc $\left(\mathrm{d}_{001}=12.54 \AA\right) .{ }^{[30]}$ While its position does not match with the known positions of the first two diffraction peaks of $\alpha$-ZnPc with $\mathrm{d}=13.0$ and $\mathrm{d}=12.3 \AA{ }^{[38]}$ some studies show that the unit cell parameters of $\alpha-\mathrm{ZnPc}$ may vary significantly depending on the substrate temperature during thin film deposition process. ${ }^{[39-40]}$

There is no information about $\alpha-\mathrm{ZnPc}$ crystal structure in the literature, however the authors of works ${ }^{[41-42]}$ attribute a C2/c space group and approximate unit cell parameters $a=25.9, b=3.8, c=23.9 \AA$ and $\beta=90.5^{\circ}$ to $\alpha-Z n P c$. Using these data, the (200) index could be assigned to the observed peak on the diffraction pattern of $\mathrm{ZnPc}$ thin film. The diffraction peak on the $\mathrm{ZnPcF}_{4}$ pattern (Figure 6) is noticeably wider compared to that on the $\mathrm{ZnPc}$ pattern with a slight asymmetry on the right side and the maximum at $13.23 \AA$. Since the $\mathrm{ZnPcF}_{4}$ powder pattern has the first two peaks with $\mathrm{d}_{001}=13.28$ and $\mathrm{d}_{010}=12.36 \AA$ relatively close to each other, it is possible to assume that $\mathrm{ZnPcF}_{4}$ thin films consist of the same crystal phase as its polycrystalline powder, and the single observed peak is actually overlapping of the (001) and (010) peaks. The diffraction pattern of the film $\mathrm{ZnPc} / \mathrm{ZnPcF}_{4}$ obtained by co-evaporation of $\mathrm{ZnPc}$ and $\mathrm{ZnPcF}_{4}$ powders also has a single peak, indicating that this film contains only one crystalline phase. The measured interplanar distance of this peak perfectly matches with $\mathrm{d}_{001}$ in the pattern of a $\mathrm{ZnPcF}_{4}$ film (note that this value significantly differs from that for $\mathrm{ZnPc} / \mathrm{ZnPcF}_{4}$ thin film which was equal to $12.77 \AA$, as reported by Schwarze et al. ${ }^{[23]}$ ). It is difficult to make any conclusion about the film orientation and crystal phase composition based on the position of only one diffraction peak.

In order to obtain more reliable and informative X-ray diffraction data, all three thin film samples were studied using measurements in 2D GIXD geometry. The resulting $2 \mathrm{D}$ diffraction patterns are shown in Figure 7. All
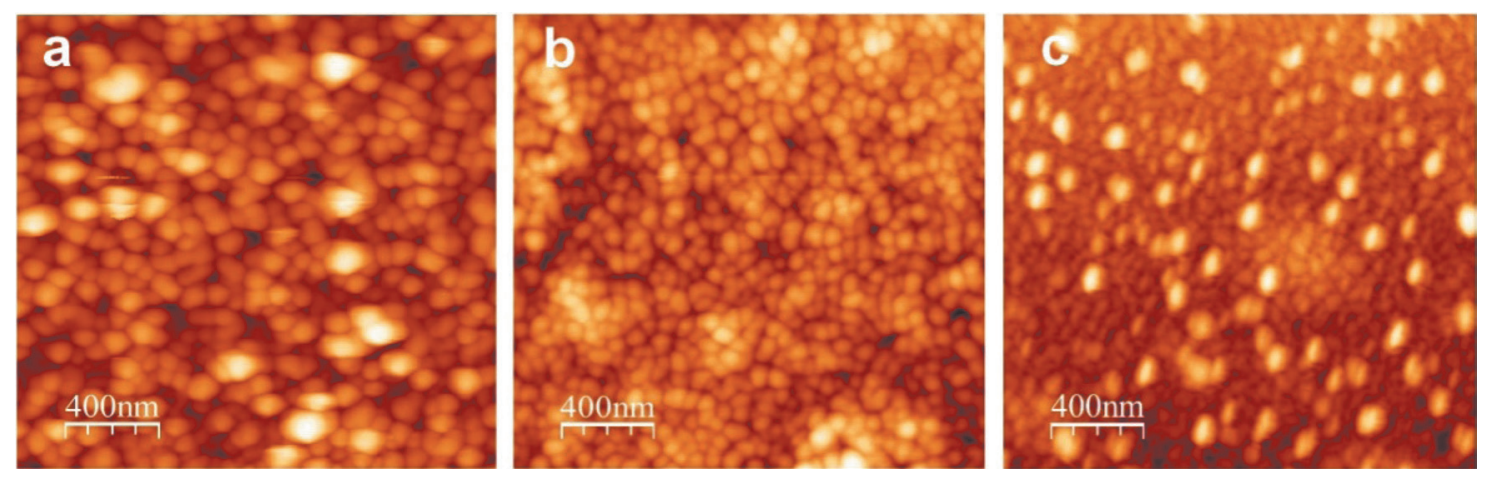

Figure 5. $\mathrm{AFM}$ images of the surface of $\mathrm{ZnPc}^{(a)}, \mathrm{ZnPcF}_{4}$ (b) and $\mathrm{ZnPc} / \mathrm{ZnPcF}_{4}$ (c) films. 


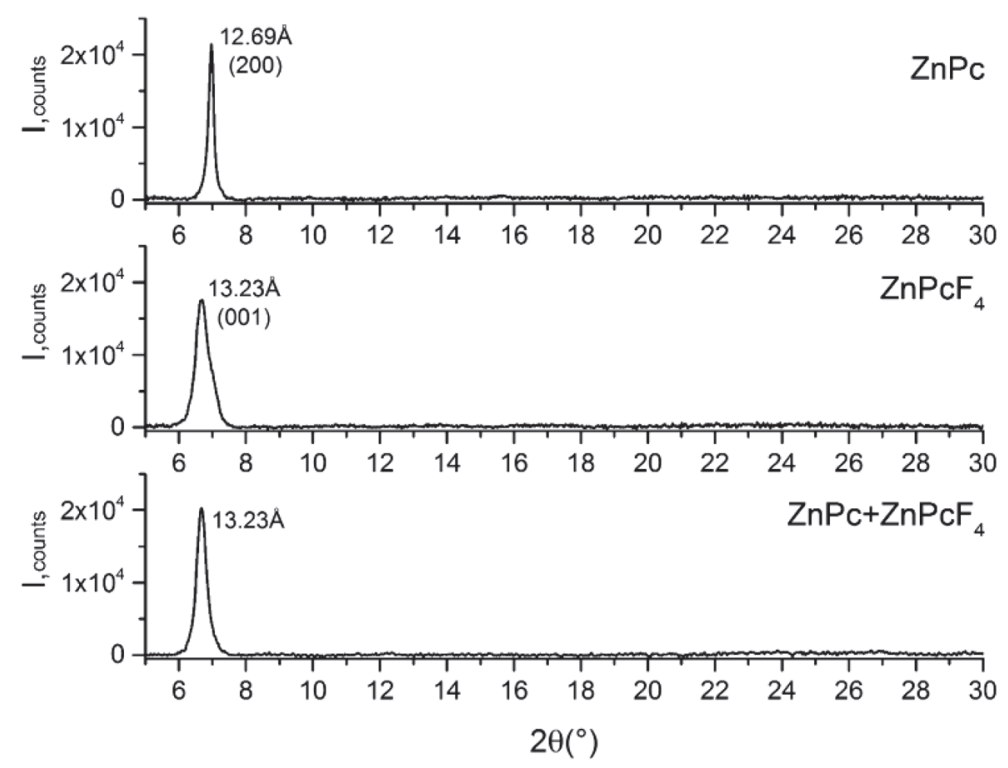

Figure 6. X-ray diffraction patterns of $\mathrm{ZnPc}_{2} \mathrm{ZnPcF}_{4}$ and $\mathrm{ZnPc}_{\mathrm{ZnPcF}}$ thin films (Shimadzu XRD-7000, CuK -radiation, Bragg-Brentano geometry).

three samples show localized diffraction spots rather than uniform diffraction arcs, which confirms our assumption of preferential orientation of thin film samples. Each diffraction spot is characterized by $2 \theta$ position, which corresponds to a certain crystallographic plane and azimuthal angle $\varphi$ (shown in Figure 7 on ZnPc diffraction pattern), which is the angle between the corresponding crystallographic plane and the substrate surface. ${ }^{[28]}$ Since the azimuthal angle $\varphi$ is equal to $0^{\circ}$ for the plane of the preferred orientation of crystallites, it means that it is parallel to the substrate surface. Therefore the measured azimuthal position of the individual diffraction spot effectively shows the angle between a corresponding crystallographic plane and a preferred orientation plane.

The white arrow on the $\mathrm{ZnPc}$ pattern shows a zero position for $\varphi$ angle, thus the displayed $\varphi$ range of each $2 \mathrm{D}$ GIXD pattern is $\pm 90^{\circ}$. The fact that each diffraction pattern has only one diffraction spot at $\varphi=0^{\circ}$ indicates

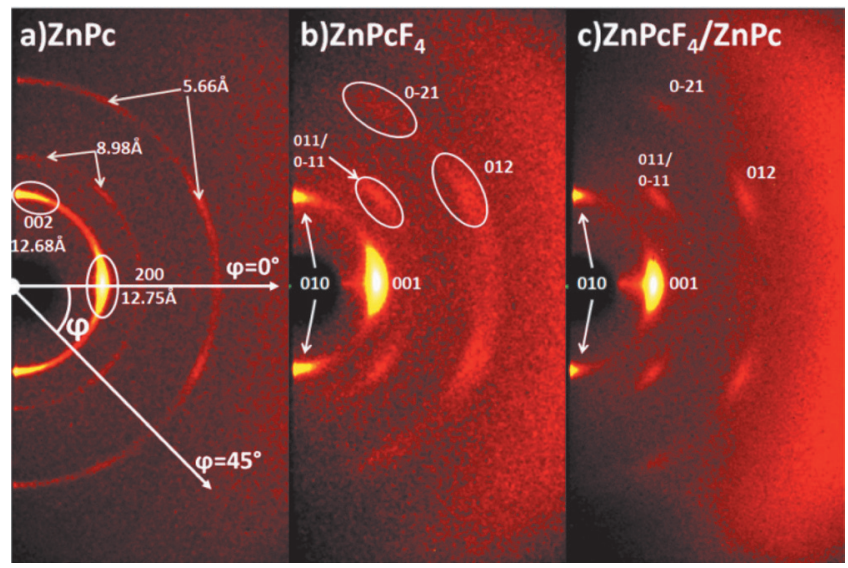

Figure 7. 2D GIXD patterns ( $80 \mathrm{~mm}$ sample-to-detector distance, $\mathrm{CuK}_{\alpha}, 0.3^{\circ}$ primary beam angle of incidence) for (a) $\mathrm{ZnPc}$, (b) $\mathrm{ZnPcF}_{4}$ and (c) $\mathrm{ZnPc} / \mathrm{ZnPcF}_{4}$ films that all three samples have only one direction of the preferred orientation. On the diffraction pattern of $\mathrm{ZnPc}$ film the first diffraction ring contains two localized maximums: one in the center with $\mathrm{d}_{200}=12.75 \AA$ and the other at about $90^{\circ}$ with $\mathrm{d}_{002}=12.68 \AA$. The presence of these two peaks proves that $\mathrm{ZnPc}$ film contains a crystalline phase different from $\beta$-ZnPc, since the (001) peak of $\beta$-ZnPc has only one equivalent Friedel pair $((001)$ and $(00-1))$ and thus would look like a single diffraction spot on the 2D GIXD pattern. Other diffraction arcs on the ZnPc pattern have several local maximums, however all maximums on the same ring have the same (or indistinguishably close) interplanar distances. All measured $\mathrm{d}$ with the assigned hkl indexes are listed in Table 2 in comparison with $\beta$-ZnPc and $\alpha$-ZnPc. ${ }^{[30,38]}$

The $\mathrm{ZnPcF}_{4}$ pattern (Figure 7) shows more localized albeit blurry diffraction spots, meaning that $\mathrm{ZnPcF}_{4}$ film has the preferred orientation along (001) plane and lower degree of crystallinity compared to a ZnPc film. All observed diffraction spots match with $\mathrm{ZnPcF}_{4}$ crystal structure data. The 2D GIXD pattern of the mixed $\mathrm{ZnPc} / \mathrm{ZnPcF}_{4}$ film (Figure 7c) looks almost similar to that of $\mathrm{ZnPcF}_{4}$, but with the clearer diffraction spots. $2 \theta$ and $\varphi$ positions of the spots match with those of $\mathrm{ZnPcF}_{4}$, which means that crystal structure of the mixed $\mathrm{ZnPc} / \mathrm{ZnPcF}_{4}$ film is very close or identical to $\mathrm{ZnPcF}_{4}$ Therefore it is possible to assign hkl indexes to all visible diffraction spots by analogy with the $\mathrm{ZnPcF}_{4}$ film pattern.

Figure 8 compares azimuthal profiles of diffraction spots (200) for $\mathrm{ZnPc}$ and (001) for $\mathrm{ZnPcF}_{4}$ and $\mathrm{ZnPc} / \mathrm{ZnPcF}_{4}$ films in the $\varphi$ range of $-30 \div 30^{\circ}$. Since all three films have preferred orientation along the selected plane, the azimuthal profile of the respective diffraction spot effectively shows the distribution of crystallites over the inclination angles relative to the substrate surface.

The fitting procedure of azimuthal profile using a Voigt function gives the values of FWHM 14.04, 16.02 and $12.50^{\circ}$ for $\mathrm{ZnPc}, \mathrm{ZnPcF}_{4}$ and $\mathrm{ZnPc} / \mathrm{ZnPcF}_{4}$ films, respectively. 
Influence of Fluorosubstitution on the Structure of Zinc Phthalocyanine Thin Films

Table 2. Measured interplanar distances (d) of $\mathrm{ZnPc}$ thin film compared to polycrystalline sample and literature data.

\begin{tabular}{cccc}
\hline ZnPc thin film, d $(\AA)$ & ZnPc powder, d $(\AA)$ & $\beta$-ZnPc, d $(\AA)^{[30]}$ & $\alpha-Z n P c, d(\AA)^{[38]}$ \\
\hline 12.75 & 12.56 & 12.54 & 13.0 \\
12.68 & 9.51 & 9.48 & 12.3 \\
8.98 & 8.31 & 8.31 & 10.1 \\
6.33 & 7.01 & 6.99 & 9.54 \\
5.66 & 6.28 & 6.27 & 8.90 \\
& 5.72 & 5.72 & 5.70 \\
\hline
\end{tabular}

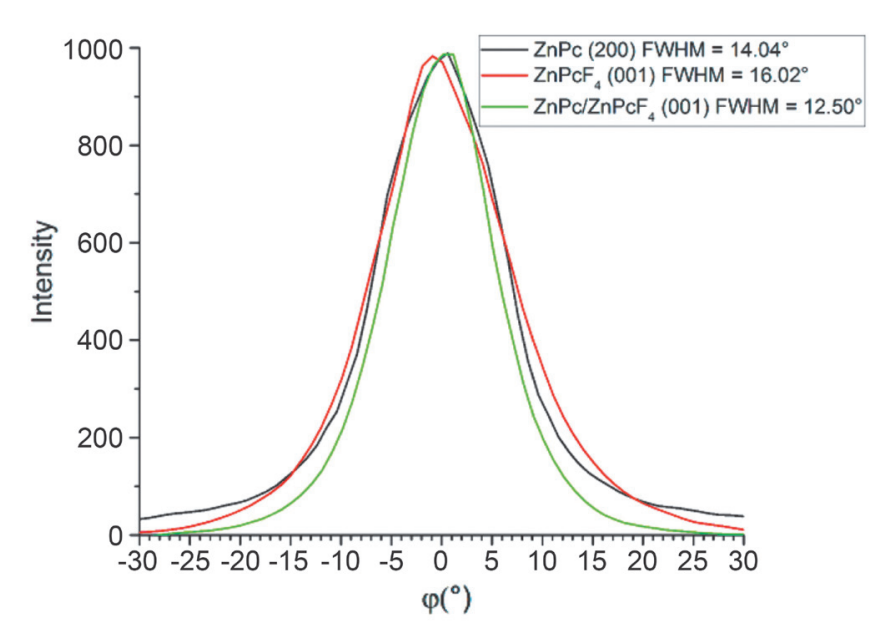

Figure 8. Azimuthal profiles of (200) peak for $\mathrm{ZnPc}$ and (001) peaks for $\mathrm{ZnPcF} 4$ and $\mathrm{ZnPc} / \mathrm{ZnPcF}_{4}$ films.

This means that the $\mathrm{ZnPc} / \mathrm{ZnPcF}_{4}$ film has the best ordering among these three samples. It is necessary to mention that in the case of $\mathrm{ZnPc}$ film the (200) peak profile does not reach zero intensity at $\pm 30^{\circ} \phi$ (Figure 8 ). This fact indicates that the $\mathrm{ZnPc}$ film has a significant portion of completely disordered crystallites.

Since crystal structure and preferred orientations for $\mathrm{ZnPcF}_{4}$ are known, it is possible to calculate the angle between substrate surface and phthalocyanine macrocycles (Figure 9). The inclination angle is equal to $80^{\circ}$ with

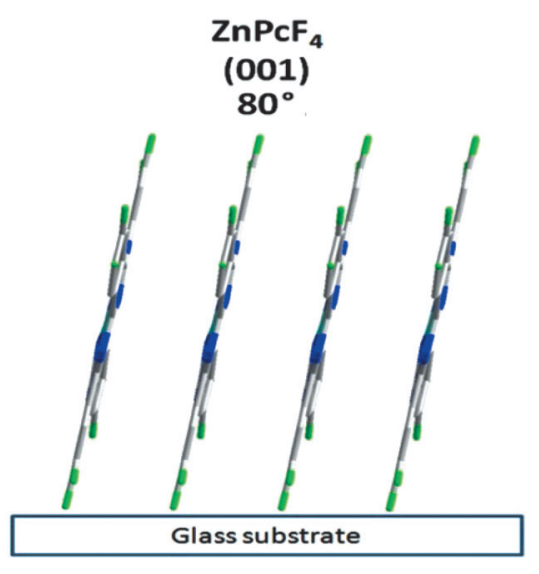

Figure 9. Orientation of $\mathrm{ZnPcF}_{4}$ molecules relative to the substrate surface. the deviation of $\pm 16.0^{\circ}$ as calculated from the azimuthal profile (Figure 8). The same inclination angle is also observed in the case of $\mathrm{ZnPc} / \mathrm{ZnPcF}_{4}$ film but with the less $\left( \pm 12.5^{\circ}\right)$ deviation from the mean value. For comparison, the inclination angle of $\beta$ - $\mathrm{ZnPc}$ film is $76.3^{\circ}$, as calculated from the structural data.

\section{Conclusions}

In this work, zinc phthalocyanine $\mathrm{ZnPc}$, tetrafluorosubstituted zinc phthalocyanine $\mathrm{ZnPcF}_{4}$ and mixed 1:1 $\mathrm{ZnPc} / \mathrm{ZnPcF}_{4}$ thin films were deposited by organic molecular beam deposition and studied to reveal the effects of F-substituents on the $\mathrm{ZnPcF}_{4}$ films structure. The crystal structure of the $\mathrm{ZnPcF}_{4}$ single crystal has been determined for the first time. $\mathrm{ZnPcF}_{4}$ is shown to crystallize in the triclinic $P-1$ space group, forming stacks of molecules in columnar arrangement; the unit cell parameters are $Z=1, a=3.6843(5) \AA, b=12.381(2) \AA, c=13.371(2) \AA$, $\alpha=88.368(5)^{\circ}, \beta=88.621(4)^{\circ}, \gamma=84.956(5)^{\circ}$. A combination of spectral ellipsometry, atomic force microscopy and diffraction techniques have been used to elucidate the structural features and molecular orientation of thin films. It has been shown that co-evaporation of $\mathrm{ZnPc}$ and $\mathrm{ZnPcF}_{4}$ results in the formation of single-phase thin film with crystal structure identical to $\mathrm{ZnPcF}_{4}$. Both $\mathrm{ZnPcF}_{4}$ and $\mathrm{ZnPc} /$ $\mathrm{ZnPcF}_{4}$ films have a preferred orientation along (001) plane with inclination angle of molecules relative to the substrate surface equal to $80^{\circ}$ and the lower degree of crystallinity compared to the $\mathrm{ZnPc}$ film.

Acknowledgements. The authors acknowledge FASO of Russian Federation for a financial support (project 03002016-0007).

\section{References}

1. Bouvet M., Gaudillat P., Suisse J.-M. J. Porphyrins Phthalocyanines 2013, 17, 913-919.

2. van Staden J.(K.)F. Talanta 2015, 14, 75-88.

3. Chen Y., Xiao Y., Su Z., Shao X., Wang S., Li X. Mater. Lett. 2017, 191, 17-21.

4. Shao X., Wang S., Li X., Su Z., Chen Y., Xiao Y. Dyes Pigments 2016, 132, 378-386.

5. Sun Y., Li X., Wang S., Zhang L., Ma F. Mater. Trans. 2017, 58, 103-106.

6. Klyamer D.D., Sukhih A.S., Krasnov P.O., Gromilov S.A., Morozova N.B., Basova T.V. Appl. Surf. Sci. 2016, 372, 79-86. 
7. Sukhikh A.S., Klyamer D.D., Parkhomenko R.G., Krasnov P.O., Gromilov S.A., Hassan A.K., Basova T.V. Dyes Pigments 2018, 149, 348-355.

8. Klyamer D.D., Sukhih A.S., Gromilov S.A., Krasnov P.O., Basova T.V. Sensors 2018, 18, 2141.

9. Ye R., Baba M., Oishi Y., Mori K., Suzuki K. Appl. Phys. Lett. 2005, 86, 253505.

10. Ye R., Baba M., Suzuki K., Mori K. Appl. Surf. Sci. 2008, 254, 7885-7888.

11. Jiang H., Hu P., Ye J., Li Y., Li H., Zhang X., Li R., Dong H., Hu W., Kloc C. Adv. Mater. 2017, 29, 1605053.

12. Yoon S.M., Song H.J., Hwang I.-C., Kim K.S., Choi H.C. Chem. Commun. 2010, 46, 231-233.

13. Pandey P.A., Rochford L.A., Keeble D.S., Rourke J.P., Jones T.S., Beanland R., Wilson N.R. Chem. Mater. 2012, 24, 1365-1370.

14. Jiang H., Ye J., Hu P., Wei F., Du K., Wang N., Ba T., Feng S., Kloc C. Sci. Reports 2014, 4, 7573.

15. de Oteyza D.G., Barrena E., Osso J.O., Sellner S., Dosch H. J. Am. Chem. Soc. 2006, 128, 15052-15053.

16. Engel M.K. Single-Crystal Structures of Phthalocyanine Complexes and Related Macrocycles. In: The Porphyrin Handbook (Kadish K.M., Smith K.M., Guilard, Eds.) San Diego: Academic Press, 2003. p. 1-242.

17. Kuzumoto Y., Matsuyama H., Kitamura M. Jpn. J. Appl. Phys. 2014, 53, 04ER16.

18. Yang J., Yim S., Jones T.S. Sci. Reports 2015, 5, 9441.

19. Hesse K., Schlettwein D. J. Electroanal. Chem. 1999, 476, $148-158$.

20. Schollhorn B., Germain J.P., Pauly A., Maleysson C., Blanc J.P. Thin Solid Films 1998, 326, 245-250.

21. Ma X., Chen H., Shi M., Wu G., Wang M., Huang J. Thin Solid Films 2005, 489, 257-261.

22. Brinkmann H., Kelting C., Makarov S., Tsaryova O., Schnurpfeil G., Wöhrle D., Schlettwein D. Phys. Status Solidi A 2008, 205, 409-420.

23. Schwarze M., Tress W., Beyer B., Gao F., Scholz R., Poelking C., Ortstein K., Günther A.A., Kasemann D., Andrienko D., Leo K. Science 2016, 352, 1446-1449.
24. Peisert H., Knupfer M., Fink J. Synth. Met. 2003, 137, 869-870.

25. Peisert H., Knupfer M., Fink J. Surf. Sci. 2002, 515, 491498.

26. Spesivtsev E.V., Rykhlitskii S.V., Shvets V.A. Optoelectron. Instrum. Data Process. 2011, 47, 419-425.

27. Tompkins H.G., Irene E.A. Handbook of Ellipsometry. New York: William Andrew Publishing, 2005. 886 p.

28. Sukhikh A.S., Basova T.V., Gromilov S.A. Acta Phys. Pol., A 2016, 130, 889-891.

29. Sukhikh A.S., Basova T.V., Gromilov S.A. J. Struct. Chem. 2017, 58, 953-963.

30. Scheidt W.R., Dow W. J. Am. Chem. Soc. 1977, 99, 1101-1104.

31. Bruker Advanced X-Ray Solutions, Madison, Wisconsin, USA.

32. Dolomanov O.V., Bourhis L.J., Gildea R.J., Howard J.A.K., Puschmann H. J. Appl. Cryst. 2009, 42, 339-341.

33. Sheldrick G.M. Acta Cryst. A 2015, A71, 3-8.

34. Sheldrick G.M. Acta Cryst. C 2015, C71, 3-8.

35. Ballirano P., Caminiti R., Ercolani C., Maras A., Orru M.A. J. Am. Chem. Soc. 1998, 120, 12798-12807.

36. Novotny M., Bulir J., Bensalah-Ledoux A., Guy S., Fitl P., Vrnata M., Lancok J., Moine B. Appl. Phys. A. 2014, 117, 377-381.

37. Rand B.P., Cheyns D., Vasseur K., Giebink N.C., Mothy S., Yi Y., Coropceanu V., Beljonne D., Cornil J., Bredas J.-L., Genoe J. Adv. Funct. Mater. 2012, 22(1), 1-9.

38. Kobayashi T., Uyeda N., Suito E. J. Phys. Chem. 1968, 72, 2446-2456.

39. Kment S., Kluson P., Drobek M., Kuzel R., Gregora I., Kohout M., Hubicka Z. Thin Solid Films 2009, 517, 52745279.

40. Senthilarasu S., Hahn Y.B., Lee S-H. J. Mater. Sci. - Mater. Electron. 2008, 19, 482-486.

41. Zanfolim A.A., Volpati D., Olivati C.A., Job A.E., Constantino C.J.L. J. Phys. Chem. C 2010, 114, 12290-12299.

42. Ashida M., Uyeda N., Suito E., Bull E. Chem. Soc. Jpn. 1966, 39, 2616-2624. 